\title{
Serving a heterogeneous Muslim identity? Private governance arrangements of halal food in the Netherlands
}

\author{
Laura Kurth $^{1} \cdot$ Pieter Glasbergen ${ }^{1}$
}

Accepted: 4 April 2016/Published online: 25 April 2016

(C) The Author(s) 2016. This article is published with open access at Springerlink.com

\begin{abstract}
The consumption of halal food may be seen as an expression of the Muslim identity. Within Islam, different interpretations of 'halal' exist and the pluralistic Muslim community requests diverse halal standards. Therefore, adaptive governance arrangements are needed in the halal food market. Globalization and industrialization have complicated the governance of halal food. A complex network of halal governors has developed from the local to the global level. In this paper, we analyze to what extent halal certification bodies in the Netherlands address the needs of the Muslim community and how they are influenced by international halal governance. The Netherlands serves as a case study with its growing Muslim community and its central position in international trade. The data comes from literature review and eleven qualitative semi-structured interviews with the most prominent actors in the Dutch halal governance system. Our analysis shows that the halal governance system in the Netherlands is weakly institutionalized and hardly adaptive to the needs of a heterogeneous Muslim community. Improvements are needed concerning stakeholder engagement, transparency, accessibility, impartiality and efficiency.
\end{abstract}

Keywords Halal · Islam · Identity · Food · Governance · Certification

Laura Kurth

laura.kurth@maastrichtuniversity.nl

Pieter Glasbergen

pieter.glasbergen@maastrichtuniversity.nl

1 International Centre for Integrated Assessment and Sustainable Development, Maastricht University, P.O. Box 616, 6200 MD Maastricht, The Netherlands

\author{
Abbreviations \\ ASEAN Association of Southeast Asian Nations \\ CBs Certification bodies \\ CEN European Committee for Standardization \\ CMO Contactorgaan Moslims en Overheid \\ GMOs Genetically modified organisms \\ HFFIA Halal Feed and Food Inspection Authority \\ IHI International Halal Integrity Alliance \\ Alliance \\ ISEAL International Social and Environmental \\ Accreditation and Labelling \\ JAKIM Department of Islamic Development \\ Malaysia \\ MUI Indonesian Ulama Council \\ MUI Assessment Institute for Foods, Drugs and \\ LPPOM Cosmetics Indonesian Council Of Ulama \\ NGOs Non-governmental organizations \\ SMIIC The Standards and Metrology Institute for the \\ Islamic Countries \\ WHC World Halal Council \\ WHFC World Halal Food Council
}

\section{Introduction}

In the last century, the food sector has developed considerably and technical innovations created a need for food standards. Governmental, intergovernmental and private institutions introduced health and safety standards. In the 1990 s, a second category of sustainability standards emerged, aiming to regulate the environmental and social conditions of food production, while securing economic viability (Fuchs and Kalfagianni 2010; Fuchs et al. 2011). 
These standards are based on moral considerations and non-governmental organizations (NGOs) often play a role in their initiation, whether or not in collaboration with businesses and governmental organizations. Meanwhile, these standards have created new business opportunities, particularly in niche markets, and certificates serve as marketing tools (Bitzer and Glasbergen 2015). Research is abundant on these governance mechanisms; topics of research are for example the development of the standards (Lewandowski and Faaij 2006; Bartley 2003; Glasbergen 2007), their legitimacy (Bernstein and Cashore 2007; Hachez and Wouters 2011; Steffek 2009), and their effectiveness (KPMG 2013; Blackmore et al. 2012; Quaedvlieg et al. 2014). Almost all standards that have been studied can be labelled as secular. This is remarkable, as there is a growing third category of standards which are inspired by and express a religious and cultural identity.

In multicultural societies, religiously inspired food standards assist in the creation of group boundaries (Fischler 1988; Mintz and Du Bois 2002) and help immigrants, which form a religious minority in the receiving countries, to reconnect with their original culture (Weller and Turkon 2015). They are an expression of religious and cultural identity. The largest religious minority in European multicultural societies adheres to some form of Islam. In Muslim tradition, religious food standards are derived from the Quran and the Sunna (the prophets' words and practices), as well as from Ijma ("a consensus of legal opinion"), and Qiyas ("reasoning by analogy") (Regenstein et al. 2003, p. 111). These sources demonstrate which foods are halal (permitted) and haram (prohibited). In general, these food standards entail the prohibition of the consumption of certain animals, blood, carrion, intoxicants and the prescription of the method of slaughtering including a blessing (Regenstein et al. 2003). Yet, the lack of one central authority in Islam, the diversity in ethnical background and degree of religiosity, as well as demographics, such as age, gender and education create diverse views on halal worthiness. For example, while some Muslims consider the consumption of halal food unnecessary in a secular context, others find the strict compliance with Islamic laws of utmost importance. For some, halal compliance is a technical problem with technical solutions, while for others it is a moral issue that needs religious devotion. Issues of contestation are, for example, slaughter practices, and the use of genetically modified organisms (GMOs) and alcohol.

The global halal food market is growing. While in 2013, halal food constituted $17.7 \%$ of global food expenditure, its share is estimated to rise to $21.2 \%$ by 2019 (Thomson Reuters 2014). Industrialization and globalization have made surveillance of the halal production chains increasingly difficult (Havinga 2010). Halal is a credence quality attribute, which depends on the origin, nature and production process of products and can hardly be assessed from the final product, but depends on the monitoring of the whole production chain (Bonne and Verbeke 2008a). In the last decades, a variety of halal governance structures have been developed in different states. While some states regulate the governance of halal food through a central agency in a hierarchical way, others lack such public institutional structures. In European multicultural societies, NGOs and commercial certification businesses, so called certification bodies (CBs), develop halal standards and issue certificates. Regional organizations in Southeast Asia, Europe and the Middle East, as well as global NGOs are trying to harmonize this multiplicity of halal standards. Existing research regarding these halal governance structures has covered consumer behavior with regard to halal food (Tieman et al. 2013; Khenfer and Roux 2012; Bonne and Verbeke 2006, 2008b); proposals to introduce halal assurance systems (Tieman and Ghazali 2014; Bonne and Verbeke 2008a); governance systems and perspectives on halal in different countries (Fischer 2008, 2015); global halal politics (Bergeaud-Blackler et al. 2015); and combinations thereof (Van der Spiegel et al. 2012). Some discuss how the supply side has influenced the development of the European halal food market and its diversity (Lever and Miele 2012; Van Waarden and Van Dalen 2013). In this paper, we aim to bridge the gap between the information about the supply side of halal certification and the demand for halal food by consumers. Especially, in multicultural states with a heterogonous Muslim community and noninstitutionalized governance arrangements it is not clear in how far the needs of the Muslim consumers are represented by CBs. Therefore we will analyze to what extent halal CBs in the Netherlands address the needs of the Muslim community and what is the influence of the international halal governance.

The Netherlands serves as a case study due to its immigration history, its reputation as multicultural society and its central position in international trade. In the 1960s/ 70 s the Netherlands experienced a wave of organized work migration, mainly bringing Muslims from Turkey and Morocco to the country, which now form the largest Islamic group. Later migration waves of asylum seekers brought Muslims inter alia from Afghanistan, Iraq, Iran, Somalia, and lately from Syria to the Netherlands. Multiculturalist policies gave a lot of freedom to the Islamic groups to establish their own lifestyle. Since the 2000s, voices rose in politics and the public to limit this freedom (Sleegers 2007). At the same time, the Netherlands has an industrialized and export-oriented food sector and due to its large harbor, the country plays a major role in the trade of halal food within Europe, as well as in the Middle East and Africa (Van der Spiegel et al. 2012). Five large formal and 
many small informal halal CBs have developed to regulate the growing halal market. The former also facilitate the requirements for halal certificates by some export markets. Understanding the extent to which halal CBs fulfil the needs of the Dutch Muslim community and the influence of international halal governance gives insights in the governance challenges arising from a globalized food market combined with the heterogenization of values in multicultural societies. Our framework for the assessment of the responsiveness of the Dutch halal CBs entails four elements: the correspondence of the halal standards with the heterogeneity of the Muslim community; the adaptation of the CBs to the cultural and ethnic heterogeneity of the Muslim community; the framing of the governance problem and resulting governance practices and; the strategies different CBs use to legitimize their actions towards the consumers. In the conclusion, we use the International Social and Environmental Accreditation and Labelling (ISEAL) credibility principles to evaluate how the Dutch halal CBs could improve their strategies and actions in order to create positive impact to the heterogeneous Muslim community. ISEAL gives a guideline for the essentials that lead a standard setting system to create positive impact and has been embraced by large sustainability standard setters, such as the Forest Stewardship Council and Fairtrade. It may be able to assist halal CBs in delivering positive impact to the heterogeneous Muslim community in multicultural societies.

In the following section, we explain the methodology and methods used for the analysis. Then, we elaborate on the heterogeneity of the Dutch Muslim community and its demand for halal standards. Thereafter, we give an account of the halal governance system globally, and the Dutch halal food market and its mechanisms more specifically. In the next step, we explain our theoretical framework and analyze the Dutch halal governance system regarding its adaptability to the Dutch Muslim community and the influence by the international halal governance structure. Finally, we discuss how the Dutch halal CBs could improve their adaptability to the needs of the Dutch Muslim community.

\section{Methods}

In this paper, we take a constructivist approach, meaning that we consider the social reality of halal food governance as constructed by the people involved. This implies that there are a range of interpretations of the nature of halal governance. Yet, within the constructivist tradition we embrace critical relativism, which entails that even though reality is socially constructed, human perception is influenced by the underlying social, political and economic structure. The methods used for our data collection come forth from this methodological approach. We executed a literature review to gain insights in the social, political and economic structure of the governance system. There is a growing interest in the topic and from the recent literature we developed a model of the governance structure. A case study approach was chosen for the analysis of the governance of a secular liberal state to ensure the feasibility of in-depth data collection from the key actors involved in the process. The insights and conclusions drawn from this case study may not be generalizable for all secular liberal states, but some general potential flaws of private halal governance systems can be identified. In order to gain insights in the experiences and interpretations of the key actors in the field of halal governance in the Netherlands, we conducted semi-structured interviews with the five largest CBs in the Netherlands, of whom one is also representing a metagovernor, in order to gain insights in the operations of these CBs, their development of halal standards and their stakeholder engagement. Moreover, we interviewed a former employee of the Contactorgaan Moslims en Overheid (CMO), an umbrella organization representing $84 \%$ of the Dutch mosques to the government (CMO 2015) and an information center for halal food to understand the needs of the Dutch Muslim community and their relation to the halal $\mathrm{CBs}$; one halal food producer was interviewed to gain insights into their role as connecting market force between the halal $\mathrm{CB}$ and the consumer. Finally, we interviewed a Turkish halal CB, whose director is representing a metagovernor and two representatives of regional governors to investigate the relationship between the Dutch halal CBs and the international halal governance initiative. ${ }^{1}$ All interviews were recorded. Nine interviews were conducted in Dutch and two in Turkish. The Turkish interviews were translated in summary to English. All interviews were deductively coded with the coding software MAX QDA to allow a structured analysis. Although the sample size of eleven semi-structured interviews is small, the data collected has been triangulated with the literature on other case studies, a policy report from a $\mathrm{CB}$ as well as information from the actors' websites, their standards and procedures. One of the authors also visited the first Halal Expo 2015 in Eindhoven and talked to several exhibitors as well as visitors.

\footnotetext{
${ }^{1}$ Five of these interviews were conducted by one of the authors in the framework of the production of a Dutch television documentary regarding the halal worthiness of Dutch halal products and the role of halal certification therein (Moslim Omroep 2015). Yet, we would like to state that the result of this research is independent from the documentary and no conflict of interest exists.
} 


\section{Diversity within the Dutch Muslim community and its halal consumption}

Even though many Muslims identify themselves as members of the global Ummah (the Islamic community) (Khan 2000), when looking at studies by authors from the Middle East, instead of "unification we see internal pluralism, ethnic diversity and multiple discourses" (Manger 1999, p. 3). In the literature, we found this pluralism on three levels; religious-institutionally, societally and individually. Religious-institutionally, there is no single authority in Islam. Instead, it is separated in denominations, schools and sects. There are two main denominations, Shia and Sunni. Within Sunni Islam, which comprises $75 \%$ of all Muslims in the world, there are four religious schools (Van der Spiegel et al. 2012) with different interpretations of the religious texts and practices. Ijma and Qiyas provide religious leaders with the tools to interpret the religious texts in a flexible way, which increases the diversity of interpretations (Van Waarden and Dalen 2011). Societally, cultural, historical and political differences led to the development of diverse cultures and religious practices of Islam between and within Islamic states (Bayat 2003). In his research regarding British Muslims, Khan (2000, p. 31) found that they "reflect the linguistic, cultural and racial diversity of their origins." The same may be assumed for Muslims that migrated to other secular states. Yet, even groups with the same cultural background, such as Dutch Moroccans or Turks, internally do not have "an entirely shared and homogeneous culture" (Slootman 2015, p. 11). This may be explained by the third level on which Muslims interpret the holy texts for their daily life, individually, thereby taking interpretations from different scholars into account. Gender, age, class, ethnicity and education may play a role in the development of pluralism in the Ummah as much as in any other community (Manger 1999).

In 2010, Muslims were estimated to constitute $6 \%$ of the European population and $5.5 \%$ of the Dutch population (Pew Research Center 2011). Estimates from 2007 show that the majority (69\%) of all Dutch Muslims has a Turkish or Moroccan background, while other large groups come from Surinam, Afghanistan, Iraq, Somalia and there are about 12000 Muslims with Dutch origin (CBS 2007) Due to the new migration wave towards Europe since 2014, these estimates might have changed, but no new data is available at the time of writing. The central office for statistics announced that the group of Syrians registered in Dutch municipalities has risen to 37000 in October 2015 (CBS 2015). This overview, even if outdated shows the diversity of ethnical and cultural backgrounds of the Dutch Muslim community and allows us to make assumptions about the diversity of Islamic denominations in the Dutch
Muslim community. While the majority of Turkish Muslims adheres to the Hanafi school of thought, with a considerable Safi minority constituted of the Kurdish Turks, in Morocco the majority follows the Maliki school (Ahmad 2010). Maliepaard and Gijsberts (2012) found differences in adherence to religious practices per country of origin (see Table 1). In addition, the table reveals that many Muslims do not adhere to religious practices regularly. For example, if $42 \%$ of the Turkish survey participants visit a mosque at least once a week, it means that $58 \%$ do not. This shows the diversity with regards to religious practices within the groups.

One of the practices that have been surveyed by Maliepaard and Gijsberts (2012) is the consumption of halal food. They found that especially among Turkish, Moroccan and Somali immigrants the adherence to this religious practice is strong. Especially since the legitimacy of Islam is being questioned in Western societies, the consumption of halal food has risen, as Muslims try to reinforce their identity (Lever and Miele 2012). In research concerning halal meat consumption behavior in France, Bonne et al. (2007) found that Muslims are primarily guided by the importance they personally attach to halal meat. People with a stronger Muslim identity find religious norms more important and are more likely to rely on external advice, while those with a weaker Muslim identity make more egocentric choices. The fact that perceived availability of halal meat does not influence consumption behavior may suggest that the importance attached to halal consumption prevails over convenience. Whether a Muslim adheres to halal food laws is a voluntary decision and especially the second and third generations of Muslims in Europe think thoroughly about their food choices (Bonne et al. 2007). The major reason for first generation Islamic immigrants to buy halal food is "faith, health and respect for animal welfare, whereas the second generation tends to buy halal meat in order to continue a (cultural) tradition" (Bonne and Verbeke 2006, np). While the older generation buys its products from small ethno-shops and local butchers based on trust relationships, the younger generation is in favor of halal labelling which would simplify convenient shopping in supermarkets (Bonne and Verbeke 2008b).

Former research has shown that there are contentious matters with regard to the definition of halal food. One controversy exists concerning which foods are halal and which ones are haram. Contentious foods are e.g. seafood, insects, alcoholic ingredients of non-alcoholic food, and GMOs. For example, debates about the acceptability of GMO take place in the realm of sciences as well as among business men and religious scholars. While many argue that no prohibition exists in Islam, others counter that genetic modification means changing God's creation which 
Table 1 Religious behavior among Muslims with different origin in the Netherlands [adjusted from SCP (Sim'11; Sing'09) in Maliepaard and Gijsberts 2012]

\begin{tabular}{|c|c|c|c|c|c|c|}
\hline & Turkish $(\%)$ & Moroccan (\%) & Afghan $(\%)$ & Iraqi $(\%)$ & Iranian $(\%)$ & Somali $(\%)$ \\
\hline Visits a mosque at least once a week & 42 & 44 & 13 & 10 & 5 & 36 \\
\hline Prays five times every day & 27 & 76 & 23 & 38 & 15 & 69 \\
\hline Fasted all days during Ramadan & 66 & 93 & 44 & 50 & 16 & 72 \\
\hline Eats halal every day & 80 & 94 & 66 & 69 & 34 & 83 \\
\hline Wears a headscarf (women) & 48 & 64 & 21 & 38 & 13 & 80 \\
\hline
\end{tabular}

is prohibited (Atalan-Helicke 2015). Also, ethical concerns regarding consequences of GMOs on environmental and human health have been posed and benefits have been weighed against potential harm (Isa and Man 2014). Probably the most famous controversy revolves around the allowed stunning methods during ritual slaughter. While no single authority exists in Islam different religious rulings (fatwas) have been issued. For example, in 1977 a fatwa from Saudi Arabia allowed stunning by captive bolt and in 1978 the Al Azhar University issued a fatwa allowing stunning in countries, where it is performed. Yet, in 1995 the Al Azhar University argued that the captive bolt should not be allowed due to its effect on the animal (Anil et al. 2010). Other controversial issues in relation with ritual slaughter are the permissibility of mechanical killing, slaughter by Jewish and Christian butchers, the animal facing Mecca and recorded prayer. Also after the ritual slaughter has been performed controversies exist with regard to transportation of haram and halal meat in the same truck, eating haram food in emergency, and trust in monitoring by fellow Muslims (Anil et al. 2010; Lever and Miele 2012; Van Waarden and Dalen 2011). Attitudes towards these controversial issues may depend on religious-institutional, societal and individual criteria. Thus, it is imperative to keep the consumers informed about production processes and ingredients to enable them to consume food that suits their Muslim identity. This is done through halal governance arrangements.

\section{Multi-level halal governance}

With regard to halal food, we see governance efforts emerging on different levels and by a variety of actors (see Fig. 1). On the local level, the halal food market consists of the Islamic butcher, the farm or slaughterhouse, and the supermarket (Ahmed 2008; Bonne and Verbeke 2008a; Tieman et al. 2013). Their halal worthiness is established in four possible ways: some Islamic organizations and mosques provide information about halal worthy and -unworthy practices. Many small sellers have a trust relation with their consumers through which information about halal worthiness is supplied. Some sellers monitor their own production and issue a certificate for themselves. Moreover, there are informal certifiers, such as Imams, who give out certificates to producers that they personally know and trust (Van Waarden and Dalen 2011).

On the national level, formal governance efforts are taken in the form of halal standards or guidelines, certification and accreditation. Some states without a separation between state and religion designate their ministry of religion to create their own halal food standards, such as Malaysia. In 1981, the Malaysian Prime Minister Mahathir Mohamad institutionalized and regulated halal and placed the responsibility for halal certification with the government, where it has remained until the present (Fischer 2015). The National Industrial Standardization Committee developed a standard containing "practical guidelines for the food industry on the preparation and handling of halal food (including nutrient enhancers). It aims to set the ground rules for food products or food businesses in Malaysia" (Halal Malaysia Official Portal 2015). According to Fischer $(2015$, p. 3$)$ "over the past three decades, the Malaysian state has effectively certified, standardized, and bureaucratized halal production, trade and consumption. Malaysia is described as a model country in terms of complying with halal standards, and the country has strong halal activity in food processing and the export/import trade as reflected in its systematization and standardization of halal certification." Other states with a large Muslim population choose for a public-private partnership, such as Indonesia, which maintains strong ties with an NGO called Indonesian Ulama Council (MUI) which installed the Assessment Institute For Foods, Drugs And Cosmetics Indonesian Council Of Ulama (MUI LPPOM) to develop a halal certification system and halal assurance system. Between 2005 and 2011, the MUI LPPOM "issued at least 5896 halal certificates covering up to 97,794 product items from 3561 companies" (MUI LPPOM 2015). Several food regulations set by the government support the MUI, for example Regulation No. 69/1999 which requires the declaration of non-halal products. If products contain pork, 
Fig. 1 Multi-level halal governance structure
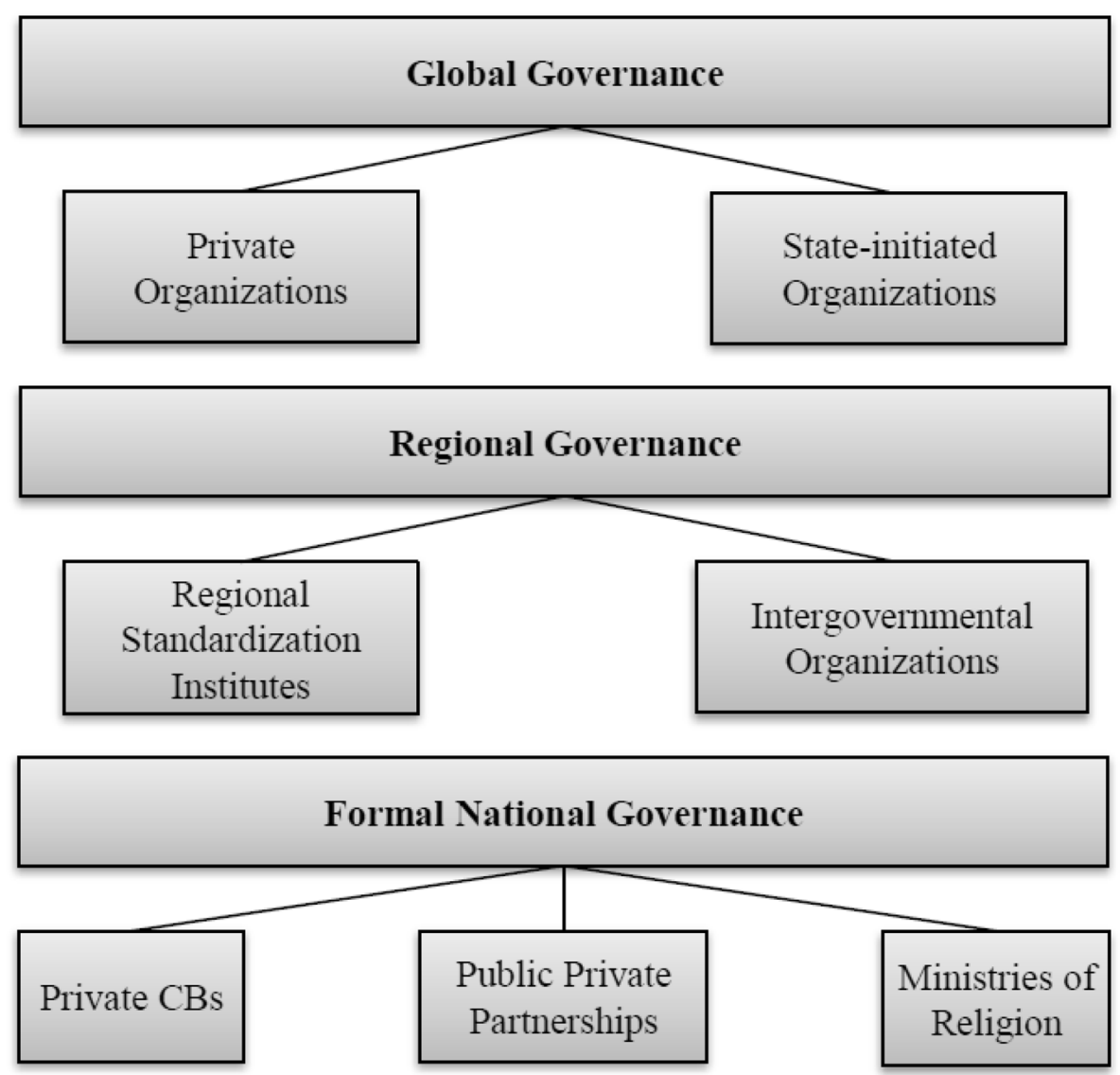

Informal Local Governance

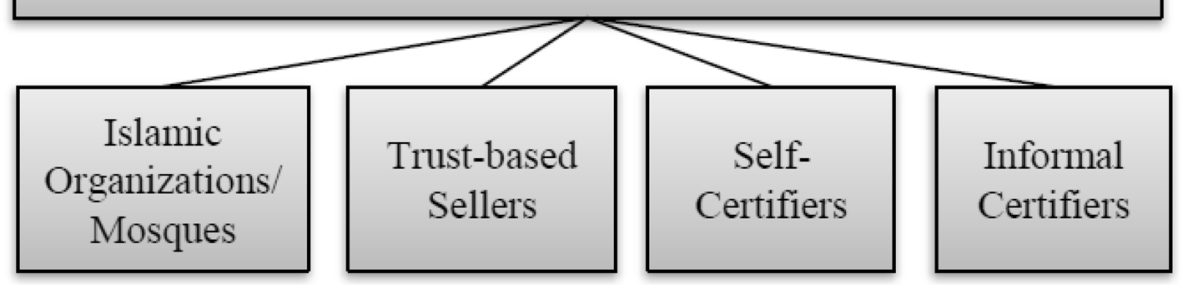

On the regional level, there are inter-governmental organizations and regional standardization institutes that are setting halal standards, such as the Association of Southeast Asian Nations (ASEAN), the Organization of Islamic Cooperation through the Standards and Metrology Institute for Islamic Countries (SMIIC) and the European Committee for Standardization (CEN). The ASEAN developed halal standards and a halal logo for its member states in 1998. The SMIIC is affiliated with the Organization of Islamic Conference and was established in 1985 in order to harmonize the standards of Islamic countries. Its statute has been signed by 23 states of which 13 have ratified it (SMIIC 2015). In 2011, the SMIIC published its General Guidelines on Halal Food and according to one of the interviewees the development of an accreditation scheme is being pursued. In 2010, upon request by 
European Islamic organizations, the CEN formed a working group to assess the feasibility of a European norm for halal food. After completion in 2012, a CEN project committee was founded, led by the Turkish Standards Institution. The CEN cooperates with national standardization committees from 33 European countries that in turn work with businesses, religious groups and NGOs in their national context.

Overarching these three levels of governance are several meta-governance bodies. "Meta-governance involves managing the complexity, plurality, and tangled hierarchies found in prevailing modes of co-ordination" (Jessop 2003, p. 108). For this purpose, the global halal meta-governance bodies are trying to create global halal standards. The most prominent ones are the World Halal Council (WHC), the World Halal Food Council (WHFC) and the International Halal Integrity Alliance (IHI Alliance). The WHFC and the WHC have a common history, as they started as one initiative in 1999 in Jakarta. In 2011, they split up and created two competing initiatives with the same objective to create global halal standards. Both work with CBs as members. According to its website, the WHC has 17 full members and 7 associated members (WHC 2015). In 2014, the WHFC had 35 members, including well-known CBs from the United States, the Netherlands, France and New Zealand (Bergeaud-Blackler 2015). It is also supported by the Malaysian and Indonesian halal authorities. The IHI Alliance was founded as a result of the World Halal Forum in 2006 with the goal to increase collaboration between halal authorities (IHI Alliance 2011a). Actors on the regional and global level of governance aim at creating global halal standards to align halal production processes globally.

From this overview of the multi-level halal governance structure we can perceive the fragmentation of this market and we can assume the power play occurring between different players. Formal halal CBs in different countries are vying for international recognition by national CBs of states with a large Muslim majority or those with state power, as well as by regional or global initiatives, that connect them to global markets. Meanwhile, different regional and global initiatives compete over influence on the world market and the creation of a halal hub. Hereby the question arises, which stakeholder should take responsibility for halal governance. Power differences occur between civil society, economic and state actors.

\section{Dutch halal governance}

The World Halal Forum estimated the size of the European halal food market to encompass $\$ 66.6$ billion with the tendency to grow larger (KasehDia Sdn Bhd 2009).
A Dutch national newspaper reported that Dutch companies request thousands of halal certificates yearly and the revenues of CBs are increasing steadily (Nolles 2015). In recent years, several scandals have given reason to doubt the halal worthiness of food. In their research using focus groups, Bergeaud-Blackler and Evans (2010) found that consumers inter alia in the Netherlands were satisfied with the supply of halal food by local butchers, while they evaluated the supply by supermarkets as average or low. While in the past, Muslim consumers in Europe avoided the consumption of haram food or substituted it with kosher alternatives, nowadays they request halal products equipped with a label (Bonne and Verbeke 2008a). Especially the second generation Muslims in Nederland is in need of halal labeling in order to guarantee the halal worthiness of products in supermarkets (Smits and Van den Berg 2003). Tieman et al. (2013) found that $68.4 \%$ of Dutch halal meat consumers would be willing to pay an additional fee for the use of a halal logistic system. Companies are willing to engage with halal production either to fulfil the request of their existing customers, or in order to expand their own market. They have the option to acquire a halal certificate which may increase their reliability and is sometimes a de facto requisite for trade with other halal producers (Havinga and Gerards 2011).

The Dutch government engages with the food market through the establishment of general laws about food production, hygiene and safety, which also apply to the production of halal food. The only aspect of halal food production that is explicitly covered by national law and extensively discussed in governmental debates is nonstunned ritual slaughter. This is mainly due to three stakeholder groups that are particularly interested in the theme: animal rights organizations, opponents of Islamization and veterinarians (Havinga 2010). In the late nineteenth century, animal protection became a major concern in the Netherlands and science received growing significance, which led to the implementation of the meat inspection law in 1919. This law prescribed stunning methods for all animal slaughter with the exemption of emergency, domestic and ritual slaughter (Wallet 2012). However, the Dutch government hesitated very long before exempting the Islamic ritual slaughter from stunning, relying on the opinion of an imam from The Hague that pre-stunning of animals is not generally prohibited (Shadid and Van Koningsveld 1992). Yet, there is no single authority in Islam that can make such a judgment for the entire Muslim community. Thus, under pressure from the Muslim community, the Dutch government finally exempted Islamic ritual slaughter from the stunning prescription in 1996 (Havinga 2010). This decision has been contested in 2011, yet did not lead to a prohibition. Besides 
that, the government is reluctant to engage with halal food governance and laws regarding labeling and certification of halal food are absent. Yet, some halal logos are legally protected from unauthorized use by civil law (Havinga 2010). This means that the logo may not be applied by a company that has not been authorized by the owner of the logo to use it. Otherwise, the government takes a liberal approach and leaves the governance of halal food to the private sector (Van Waarden and Dalen 2011).

Instead, a governance system of five large private halal CBs with auditing and monitoring procedures has been established. They finance themselves through the fees paid by suppliers and retailers for their audits. They mainly serve large slaughterhouses and producers of processed food for domestic sales and export. Three of the certification bodies are authorized to certify export products (Van Waarden and Dalen 2011). During our research, we found that the Dutch $\mathrm{CBs}$ were established in a chain reaction. The first $\mathrm{CBs}$ developed due to the need for export certificates because an opaque system of certification had progressed in the absence of governmental regulation. As the first CB explained,

during the inspections that we did, we realized that a certificate was needed for export. We realized that those people who gave these certificates had no idea about the technical issues. They gave certificates while the meat did not comply with the rules of ritual slaughter. We said that this is impossible.

To overcome these challenges, Halal Feed and Food Inspection Authority (HFFIA) started its activities in the 1960s with the establishment of the federation of Muslim organizations and became an official certifying agency in 1994 (Van Waarden and Dalen 2011). In its policy plan, HFFIA further states that the foundation was set up by Muslims to serve the need of the Dutch Muslim community (Stichting Halal Voeding en Voedsel 2014). The second CB, Halal Quality Control, was founded in 1983 focusing mainly on halal meat certification and in 1996 added certification of processed food. It is operated by the honorary consul of Syria to the Netherlands and is well connected internationally. The third formal CB, Halal Correct, said to have developed in order to supply meat products as its founder did not trust the second $\mathrm{CB}$ that mainly focused on meat production. A second motivation for this $\mathrm{CB}$ was the possibility to earn money through certification:

Thus, instead of drawing attention to the bad practices of the other CB, you offer alternatives. And you realize that the others are earning a lot of money and gain status. So you want that as well, and instead of joining them you start for yourself.

Halal International Control developed as a reaction to the former three, arguing that these are asking too much money for their services. The founder is a halal food producer who has the aim to make halal food available to people with a low budget. Nowadays, he produces and certifies products for major supermarkets. The youngest CB, Halal Audit Company, developed due to a perceived lack of clear communication strategies by the former CBs. It was set up by some young accountancy graduates who found that the existing CBs did not provide them with the answers that they were looking for to ensure the halal worthiness of their food. They argued that the third generation of Muslims in the Netherlands is more assertive and requests clearer communication, stating that

then our assertiveness appeared and we asked whether they could tell us how it is produced. Finally you receive an answer, but the CBs also say 'if I say so, just accept it'. But I wanted to understand halal. I could not receive that answer. Thus, I realized early on that there is a lack of communication.

The first three of the five CBs are recognized by Islamic states to issue halal certificates for export. They became members of the meta-governor WHFC, which gives them international recognition, especially when exporting to Indonesia and Malaysia. As an interviewee explained,

the WHFC is a club of internationally recognized certification bodies, or such that would like to be recognized by the Indonesian halal authority. Also the Malaysian authority is represented there. Thus everyone who wants to be recognized by them ends up there.

Membership in the WHFC requires a payment from the $\mathrm{CBs}$ and it is mainly used to ensure export rights rather than governing the domestic Muslim community. Two of these three $\mathrm{CBs}$ are also affiliated with the WHC, which is the precursor and competitor of the WHFC. The youngest Dutch certification body is a member of the IHI Alliance, an "international non-profit organization created to uphold the integrity of the halal market concept in global trade through recognition, collaboration and membership" (IHI Alliance 2011b). All certification bodies rejected collaborating with the $\mathrm{CEN}$, mainly due to its secular character: "The CEN hired imams, but will they take the final decision? It is just as if the government would say that they will develop rules for the protestant church."

In a letter from November 2011, HFFIA, Halal Correct, the CMO and a consumer organization (the Green Muslims Foundation) urged the Dutch standardization institute "to cancel the activities immediately and leave the question of the feasibility and need of a halal standard to the Muslim community" (CMO et al. 2011). There are divided opinions about the ability of the SMIIC to create a global standard. None of the certification bodies is a member, 
since the SMIIC consist of OIC country representatives. Yet, while some reject cooperation with the SMIIC on the basis of its economic objectives, others consider it the most fruitful initiative, due to its broad inter-governmental backing, especially if Malaysia and Indonesia would join in.

\section{Theoretical framework and analysis of the Dutch halal certification bodies}

Halal CBs mediate between halal food providers and the Muslim consumers through establishing trust and providing information about the standards used during food production, especially with regard to controversial issues. Yet, the fragmentation of the halal market and flourishing food scandals has raised doubts about the integrity of the certification process (Atalan-Helicke 2015). In 2010, a Dutch consumer program found that out of 10 lamb kebabs only one contained $100 \%$ lamb meat, while one even contained pork meat (Keuringsdienst van Waarde 2010). In 2012, a Dutch tradesman was convicted for selling South American horse meat as halal beef (Trouw 2013). We will analyze to what extent halal CBs in the Netherlands address the need of the Muslim community and what is the influence of the international halal governance. In the literature review, we saw that controversies exist with regard to halal food and that different religious groups require diverse halal standards. Therefore in the first step, we compare the halal standards and analyze differences and similarities. In the second step, we discuss the religious and ethnic orientation of the halal CBs to assess whether these aspects have been considered for the provision of halal food. In the third step, we look at different framings of the governance problem. Diagnostic or problem framing influences which governance approaches or solutions are considered feasible (Benford and Snow 2000). In the context of private halal governance, the problem framing with regard to the provision of halal food influences the attitude of Muslims towards halal food as well as the governance approaches taken by CBs. The framing of the governance problem and its possible solutions can furthermore determine to what extent the Dutch CBs take the religious needs of the Dutch Muslim community into account as compared to export requirements and other motives. Lastly, we assess how different halal CBs try to establish legitimacy. Legitimacy refers to "a generalized perception or assumption that the actions of an entity are desirable, proper, or appropriate within some socially constructed systems of norms, values, beliefs and definitions" (Suchman 1995) and therefore "recognizing the right to govern" (Coicaud 1997, p. 10). We define legitimate governors as standard setting and enforcing entities whose standards and activities are accepted by producers, retailers and consumers (Glasbergen 2013). Legitimacy challenges are particularly prominent in the realm of private governance as voluntary efforts need more justifications than other forms of authority. Moreover, the degree of legitimacy influences the effectiveness and efficiency of private governance and there are often no formal mechanisms for stakeholder involvement (Schouten and Glasbergen 2011). The legitimacy of CBs has frequently been discussed concerning sustainability standards and we consider it equally important with regard to halal certification.

\section{Little differences in standards}

Generally, it may be said that none of the CBs reinvented the wheel. While some literally took over the standards from the Department of Islamic Development Malaysia (JAKIM), others compared different existing standards, sat together with Imams and created their own standards, adapted to the European context. As a CB explained:

we compared the standards of Malaysia, Indonesia, Turkey etc. regarding their similarities and differences. We avoided all conflicting issues. We checked if this helps the halal consumers in the Netherlands and Europe and whether they accept it. Then at some point we made a summary of everything we have seen. That is our standard.

The importance of the Malaysian and other foreign standards may be explained by the use of certification mainly for the purpose of export. When CBs are recognized by foreign religious authorities their standards need to be in line with the requirements of the receiving country as a $\mathrm{CB}$ clarified:

We receive recognition by the countries such as Malaysia, Indonesia, UAE or Saudi Arabia. They visit us and recognize us, and we organize their certification. If we issue certificates on their behalves, this needs to happen according to their standards.

Content wise, we found that the formal standards used by the CBs are very similar. None of the standards was publicly available, but we received the standards of four CBs for our analysis. One CB said that "our standards are developed in cooperation with Imams. We have protocols to execute a screening and for the cleaning. We always have to discuss which protocols and exceptions to apply." Due to the adaptable nature of the standards, this CB did not provide us with its standards for analysis. Two of the four CBs use the Malaysian standard and therefore we only compared three standards in anonymized form. All standards entail a section about allowed stunning methods. While two standards prohibit the use of shooting masks, the 
third one specifies that only electrical or pneumatic percussive stunning is accepted. Yet, it may be concluded that all three standards provide for some kind of stunning. They also all require a prayer to be said wherein one does not specifically mention that the prayer has to be said by a human. Two of the three standards recommend turning the animal towards Mecca during slaughter. The third standard does not mention the issue. With regard to the use of alcohol, one standard does not give any information while one prohibits 'khamar', thus alcohol, and the other one allows ingredients with less than $0.05 \%$ while the final product has to be alcohol free. Two standards specify that they allow the consumption of all sea food except for those that are toxic and one also does not allow for animals that live simultaneously on land and in the water. The same standards also prohibit the use of GMO. All three standards require the separation between halal and haram food and the use of haram animal proteins as additives is prohibited by all of them.

From the overview in Table 2, we can understand that there are very small differences between the contentious issues within formal standards used by the CBs. This shows that the CBs hardly adapt to the heterogeneous Muslim community through the provision of a broad range of different standards, even though in practice some CBs find that their operations are largely based on conflicting standards. Instead, the CBs adjust to the requirements of international governors by applying standards in compliance with the Malaysian standard, which they perceive as the strictest standard on the market.

\section{Religious and ethnic orientations ignored}

With regard to the religious orientation the Dutch CBs are very similar. They indicate that they represent the Sunni tradition of Islam. As mentioned before, the Sunni Islam is split into four schools, but the CBs claim to account for all four schools. How they do this, however, remains questionable as there are differences between the schools regarding their interpretation of halal food standards and no differentiation is visible on the halal certificates issued by the CBs. CBs in other countries differentiate between schools by making production standards explicit on their label. The ethnicity or country affiliation of the CBs may play a role with regard to the adaptability to the heterogeneous Muslim community for two reasons: On the one hand, Muslims with a similar ethnic background may trust each other more, and on the other hand, the country affiliation of a CB may entail that it follows the advices of the religious authority in that country. The founders of the CBs are of different ethnic decent, but several of them have a mixed team with different ethnicity. Yet, their focus on Malaysia and Indonesia as the major export market, may lead them to follow the advice of JAKIM and MUI with regard to halal food standards. Thus, neither the religious orientation nor the ethnicity and country-affiliation of the different CBs have proven to increase the adaptability of the governance to the needs of the Muslim community, as none of the $\mathrm{CBs}$ promote themselves as representing a certain religious affiliation or ethnic belonging. Yet, Van Waarden and Dalen (2011) found that CBs whose founders originated from former colonies "seemed to be more used to the western approach of relying largely on science, accountability and transparency," while founders from other countries mainly operate according to the traditions in their home country. Thus, the business operation of the CBs may be influenced by historical developments in the country of origin.

\section{Different frames of the governance problem}

In our analysis of the eleven interviews, we found four major frames of the governance problem; economic, technical, religious and regulatory. Within the economic frame, a governance problem exists for three stakeholder groups; halal producers and retailers, halal CBs and governments. Halal producers and retailers are in need for ethno-marketing opportunities and export certificates. Halal certificates can act as marketing tools to gain the trust of the Dutch halal consumers. Moreover, in order to enter

Table 2 Comparison of anonymized halal food standards regarding contentious issues

\begin{tabular}{|c|c|c|c|}
\hline & Standard 1 & Standard 2 & Standard 3 \\
\hline Stunning & Yes $\neq$ shooting mask & Yes $=$ electrical/pneumatic percussive & Yes $\neq$ shooting mask \\
\hline Prayer & Yes & Yes & Yes \\
\hline Direction Mecca & Yes & Yes & Not specified \\
\hline Alcoholic ingredients & Yes $<0.05 \%$ & No & Not specified \\
\hline Seafood & Yes, except toxic & Yes, except toxic/living in sea AND land & Not specified \\
\hline GMO & No & No & Not specified \\
\hline Separation from haram & Yes & Yes & Yes \\
\hline Additives & No haram animal proteins & Only from halal animals. No excessive use & No animal proteins \\
\hline
\end{tabular}


foreign Islamic markets, a halal certification is often required. The CBs may perceive the halal governance market as an unleveled playing field. They fear unfair competition from fraudulent CBs that do not comply with the same strict standards or have less stringent monitoring procedures. As a $\mathrm{CB}$ explained, "if every $\mathrm{CB}$ would collaborate with different Imams it would not be such a problem, but that is not happening. If I say that I have to pay 30 salaries every month, I must be able to earn that money as well. It is not moneymaking, but the construct in which we work." A proposed solution is the introduction of a meta-governor that enforces strict monitoring procedures. For governments, an economic problem exists in terms of import and export barriers due to the absence of one global uniform standard. Yet, the lack of uniform standards can also be perceived as an opportunity to protect domestic markets through the introduction of strict halal standards that producers from other countries can hardly comply with.

One of the regional governors in the network described the governance problem in purely technical terms:

For $99 \%$ we are talking about production standards, a technical discussion. It has nothing to do with beliefs, but with the integrity of the food production. That is what it is about, once it is halal. What is halal then? Imagine that a piece of meat is slaughtered halal, whether stunned or not, then you need to make sure that it is not contaminated by pork meat or other haram meat. That has nothing to do with beliefs, but it is just a production process.

According to him, these technical problems should be solved by creating and enforcing technical standards that exclude the religious contentious topics. Such a frame decouples the religious nature of halal food standards from the technical production process, which makes it difficult to include the heterogeneous opinions of the Dutch Muslim community in the halal standards.

The regulatory frame focuses on the reluctance of the Dutch government to protect the term halal by creating halal standards. As an interviewee said "In the Netherlands you have laws and rules like in every other country. Halal is not registered by law. That means that someone who does not work halal worthy, but labels his products as halal, is unpunishable. But this is confusing for the consumer." Meanwhile, an information center for halal food said on its website that "there are no norms and regulations concerning the halal label, because halal is only considered a religious requirement. The lack of governmentally recognized requirements for halal certification creates skepticism towards the producers that are labeled halal" (Aaras 2015). The underlying problem addressed here is the confusion of the Dutch halal consumer. Yet, while the CBs could have proposed governmental regulation as the desired solution most of them prefer religious groups to regulate the field through standard setting and certification.

Finally, there is the religious frame, which focuses on the consequences of eating haram meat for the individual Muslim. Securing the availability of halal food, especially in countries with a Muslim minority, is considered important to ensure their spiritual health in the current and the afterlife. Some actors argued that the responsibility for the halal worthiness of the meat lies with the producers or retailers of the food if they declare it to be halal, while others see the responsibility with the consumer to investigate whether their food was produced in a halal worthy manner. A CB explained that "in the Quran it says 'Trust your brother and sister'. Yet, it also says 'you have to be sure that your trust is good'. At the moment that you start doubting you have to stop trusting. In order to doubt or trust you have to be knowledgeable". In this frame, the religious health and identity of the Muslim consumer is the central point of concern.

Whereas the economic and the technical frame primarily focus on the simplification of export and economic gain and leave little space for adaptation to the heterogeneous Muslim community, the regulatory and the religious frame put the Muslim consumer in the foreground. Each of the halal governors employs a mix of the four frames in their motivation, but generally we can conclude that the economic frame often seems to gain primacy above the other three.

\section{Different forms of legitimacy}

For the acceptability of standards and certificates to stakeholders we consider three aspects as important; stakeholder participation, external legitimation and transparency of certification processes. Stakeholder participation is especially important when formal democratic legitimation is absent. Private governance arrangements can be internally legitimized if stakeholders feel represented in the decision making processes (Nanz and Steffek 2004). Unlike most sustainability-related CBs, the Dutch halal CBs represent no partnerships between societal NGOs, halal producers and retailers, but they are either commercial certification businesses or NGOs aiming for certification. Standards are developed with the aid of handpicked imams and foreign religious authorities and monitoring occurs behind closed factory doors. The CBs neither accommodate the participation of halal producers and retailers, nor of the Muslim community. Independence of the $\mathrm{CB}$ can increase their reliability, as monitoring can be executed independently (Havinga and Gerards 2011). 
However, the CBs receive fees from the halal producers and retailers for their services, which indicate their economic dependency. The non-involvement of halal producers and retailers may be required by the absolute nature of religion, which leaves little space for negotiation. As the former representative of the CMO explained with regard to CENs' initiative to create a participatory standard setting process "how are you going to negotiate with businesses about halal? What they do not understand is that you cannot negotiate on that. There is no way of negotiating with businesses about a religious principle". Yet, since different interpretations of halal exist within the Dutch Muslim community, its participation in the standard setting and monitoring process could be crucial for the legitimacy of the CBs to the Dutch consumers.

External legitimacy refers to the governance of governance or to the question of who accredits the CBs. The Dutch CBs try to gain external legitimacy in three ways; from international governance, through private mechanisms, and by religious leaders. International governance entails the endorsement by foreign governments directly, for example through the permission to certify halal products for them. Otherwise, CBs can be accredited by regional or international meta-governors, which are legitimized by governments. A respondent explained that

the countries that import halal food are especially careful. Thus, if all of them have accepted the SMIIC, why should we not trust it? "and "in the end there will be companies and governments that will say 'I trust the EU, all the others are not as professional, and thus I trust their standard'.

Private mechanisms used to create legitimacy are brand recognition, mutual acceptance of standards, and consumer organizations. A CB explained how collaboration with a trusted supermarket chain helps his publicity: "I am delivering products to the Albert Heijn (a renowned Dutch retail chain) and I am happy. In terms of publicity, it is enormous, a lot of doors open for you. With the other supermarkets you conduct business, but the Albert Heijn is an institute". Mutual recognition of certificates was considered important by a CB as he stated that "our power is that if we reject a certificate, we often receive requests from companies whether we recognized a certain CB. If we say no, they already know enough. We have become a database for reliability". This view has been supported by a halal producer that we interviewed, who said that "I have chosen my halal $\mathrm{CB}$, because my suppliers work with the same body. We would like to keep it in one chain, so that we can always trace back our products". Other private actors that developed to monitor the $\mathrm{CBs}$ are consumer organizations, such as ikeethalal.nl and the halalpolitie, which inform consumers about the practices of the CBs and the halal worthiness of products. They create, for example, critical internet blogs, make television programs about halal food, rate halal producers regarding their halal worthiness and have created a reporting point for halal misuse. Religious legitimacy is aspired through close cooperation with leading imams and Islamic organizations in the Netherlands and abroad. Two Dutch CBs installed their own standing boards of imams from the four Sunni schools, but also the other CBs confirmed that they consult domestic and foreign imams for ambiguous matters. An interviewee argued that "even if I know the answer for sure, if I receive a question I first present it to the imams. I need to hedge myself." Moreover, some CBs designate devout Muslims to the halal producers where they monitor the halal production processes to guarantee their halal worthiness constantly.

Transparency may create legitimacy as it makes certification processes comprehensive and enables stakeholders to choose which standards and procedures they find acceptable. We assessed the transparency of the halal CBs regarding the information published on their website and the expressiveness of the halal certificates and logos. None of the $\log$ os and certificates that we analyzed entails specifications with regard to the standards that have been applied during the production process. They refer to the fulfillment of Islamic law/guidelines or their own directives/required standards, but do not specify the meaning thereof. Thus, the consumer cannot understand from the certificate according to which standards a product has been produced. Some of the CBs' websites offer some of the standards used, but give no detailed account or copy of their official standards and procedures. The representative of the information center for halal food questions whether halal certification is "reliable if the CB cannot support his answers by the criteria he uses and the Islamic law on which they are based. Then it is up to the consumer or the company to make the decision." Yet, upon request four of the five CBs disclosed their halal standards.

\section{Conclusion}

The halal governance system in the Netherlands is weakly institutionalized and hardly adaptive to the needs of a heterogeneous Muslim community. The analysis shows that the weak institutionalization manifests itself in multiple ways: Firstly, there is a complex multi-level system of certification bodies with overlapping scales and fields of governance. Secondly, the CBs are financially dependent on the halal producers and retailers that they monitor and they are economically and politically dependent on international governors for export permits. Thirdly, overlapping standards are used that are mainly determined by 
international governors due to the size of the export market. Fourthly, ethnic and religious backgrounds are neglected, while these are important signifiers of the heterogeneity in the Dutch Muslim community. Fifthly, diverse frames of the governance problem exist, which seem to be dominated by the economic frame. Finally, the governance system is opaque with regard to standards and procedures and it lacks an open participatory processes; legitimacy is sought from external actors instead.

The system does not meet the standards that have been formulated by international organizations for credible private governance of sustainable production, such as the ISEAL Alliance. In our discussion thereof, we will specifically focus on the CBs' relevance, stakeholder engagement, transparency, accessibility, impartiality and efficiency. Considering these standards reveals where improvements are necessary to create a reliable halal governance system.

One of the ISEAL credibility principles (ISEAL Alliance 2013) is relevance, which entails that the right problem is addressed, and that the requirements serve the objective, reflect scientific understanding, international norms and are adaptive to local needs. In order to apply this principle to halal governance the framing of the governance problem is crucial. When we speak of an economic governance problem an international harmonization of standards may be desirable, while a religious problem definition may involve a local adaptation of standards and transparency. Whether and how scientific insights with regard to sustainable food production should be integrated with halal food standards stays a topic of debate, exemplified in the diverse opinions with regard to pre-stunning and GMOs.

Another ISEAL principle is stakeholder engagement, which implies that a representative group of stakeholders should be invited during the process of standard creation and adaptation and that a complaint system should be in place. As explained before, the challenges with regard to stakeholder involvement lie in the tension between the universal truth of religion and diverse interpretations and implementations of religion in practice. Depending on the problem framing, there may be no room for negotiation with industry or other non-religious stakeholders for example. However, leverage with regards to governmental requirements and different interpretations of the Quran exist and should be used to serve the heterogeneous needs of the Muslim community. For this to happen, the transparency, accessibility and impartiality principles are imperative.

Transparency requires that relevant information about the development and content of the standards are freely available. This principle has found little application by the halal CBs so far. While some publish part of their standards on their website, others disclose no information, especially with regard to contested standards. In addition, the process of standard development is not explicitly mentioned on any of the CBs' websites, yet is disclosed upon request.

Accessibility requires that costs and unnecessary requirements are minimized and information about the standards, trainings and financial resources for capacity building be provided. The costs for the certification vary considerably between the different CBs (Havinga and Gerards 2011). Whether requirements are considered unnecessary is again dependent on the objective of the CB. Some CBs already offer workshops for halal producers throughout the production chain.

The principle of impartiality is crucial for the stakeholders to feel represented and taken seriously. As seen in the analysis, it appears that commercial interests and the needs of the international governors are still given preference above the needs of the Dutch Muslim community. The governance problem is mainly economically defined, standards are developed regarding the Malaysian system, ethnic and religious differences are not emphasized and participatory processes and transparency are lacking. Generally, economic interests do not have to compromise public interests, but provision of information is needed.

Finally, the ISEAL principle of efficiency suggests that the system should become efficient and cost-effective for the consumers through cooperation between schemes, sound revenue models and organizational management strategies. In our research, we have seen that the Dutch CBs use overlapping standards and for a large part fulfil the same function of facilitating export. Their geographical scope seems to be defined by demand rather than by strategic organization and cooperation. More coordination between the CBs could lead to more resource-efficient halal governance for the domestic and the international market and would allow for a better adaptation to the needs of the heterogeneous Dutch Muslim community.

Our research contributed to the body of scholarly literature by comparing the supply side of halal governance with the demand of the heterogeneous Muslim community, unraveling the underlying dependencies between different levels of governance, uncovering the effect of different framings of the governance problems and highlighting challenges that exist with regard to religious food certification and potential solutions. Further research should take the comparison of supply and demand side a step further by gaining deeper insights in the needs of the heterogeneous Muslim community, possibly by means of in-depth interviews with respondents from different age groups, ethnic background, degree of religiosity, education level etc. Moreover, further research should consider the political impact of immigration and integration on the demand and supply of halal food and the influence of international governance structures. Finally, further research should focus on increasing reliability of the halal governance system. 
Acknowledgments Hereby, we would like to thank Ebubekir Öztüre for arranging interview opportunities with a Turkish halal certification body and a regional governor. Additionally, we would like to thank all respondents for participating in our research.

Open Access This article is distributed under the terms of the Creative Commons Attribution 4.0 International License (http://crea tivecommons.org/licenses/by/4.0/), which permits unrestricted use, distribution, and reproduction in any medium, provided you give appropriate credit to the original author(s) and the source, provide a link to the Creative Commons license, and indicate if changes were made.

\section{References}

Aaras, M. 2015. Halal certificering in kaart. http://www.ikeethalal.nl/ halal-certificering-kaart/. Accessed 06 July 2015.

Ahmad, A.U.F. 2010. Theory and practice of modern Islamic finance: The case analysis from Australia. Boca Raton, Florida: BrownWalkers Press.

Ahmed, A. 2008. Marketing of halal meat in the United Kingdom: Supermarkets versus local shops. British Food Journal 110(7): $655-670$

Anil, H., M. Miele, K. Von Holleben, F. Bergeaud-Blackler, and A. Velarde. 2010. Religious rules and requirements-Halal slaughter. Dialrel Reports. http://www.dialrel.eu/images/halal-rules. pdf. Accessed 31 Mar 2016.

Atalan-Helicke, N. 2015. The halal paradox: Negotiating identity, religious values, and genetically engineered food in Turkey. Agriculture and Human Values 32(4): 663-674.

Bartley, T. 2003. Certifying forests and factories: States, social movements, and the rise of private regulation in the apparel and forest products fields. Politics \& Society 31(3): 433-464.

Bayat, A. 2003. The use and abuse of 'muslim societies'. ISIM Newsletter. https://openaccess.leidenuniv.nl/bitstream/handle/ 1887/16913/ISIM_13_The_Use_and_Abuse_of_Muslim_Societies. pdf?sequence=1. Accessed 31 Mar 2016.

Benford, R.D., and D.A. Snow. 2000. Framing processes and social movements: An overview and assessment. Annual Review of Sociology 26: 611-639.

Bergeaud-Blackler, F. 2015. Who owns halal? Five international initiatives of halal food regulations. In Halal Matters: Islam, politics and markets in global perspective, ed. F. Bergeaud-Blackler, J. Fischer, and J. Lever, 192-197. London, UK: Routledge.

Bergeaud-Blackler, F., and A. Evans. 2010. Halal consumer attitudes and opinion towards ritual slaughter. Dialrel Reports. http://www. dialrel.eu/images/factsheet-halal.pdf. Accessed 31 Mar 2016.

Bergeaud-Blackler, F., J. Fischer, and J. Lever (eds.). 2015. Halal matters: Islam, politics and markets in global perspective. London, UK: Routledge.

Bernstein, S., and B. Cashore. 2007. Can non-state global governance be legitimate? An analytical framework. Regulation \& Governance 1(4): 347-371.

Bitzer, V., and P. Glasbergen. 2015. Business-NGO partnerships in global value chains: part of the solution or part of the problem of sustainable change? Current Opinion in Environmental Sustainability 12: 35-40.

Blackmore, E., J. Keeley, R. Pyburn, E. Mangus, L. Chen, and Q. Yuhui. 2012. Pro-poor certification: Assessing the benefits of sustainability certification for small-scale farmers in Asia. In $J$, ed. I.I.E.D. Natural Resource Issues. London: Mayers.

Bonne, K., and W. Verbeke. 2006. Muslim consumer's motivations towards meat consumption in Belgium: Qualitative exploratory insights from means-end chain analysis. Anthropology of Food 5: np.

Bonne, K., and W. Verbeke. 2008a. Religious values informing halal meat production and the control and delivery of halal credence quality. Agriculture and Human Values 25(1): 35-47.

Bonne, K., and W. Verbeke. 2008b. Muslim consumer trust in halal meat status and control in Belgium. Meat Science 79(1): 113-123.

Bonne, K., I. Vermeir, F. Bergeaud-Blackler, and W. Verbeke. 2007. Determinants of halal meat consumption in France. British Food Journal 109(5): 367-386.

Campbell, H., A. Murcott, and A. MacKenzie. 2011. Kosher in New York City, halal in Aquitaine: Challenging the relationship between neoliberalism and food auditing. Agriculture and Human Values 28(1): 67-79.

CBS. 2007. Ruim 850 duizend islamieten in Nederland. http://www. cbs.nl/nl-NL/menu/themas/bevolking/publicaties/artikelen/archief/ 2007/2007-2278-wm.htm. Accessed 17 Dec 2015.

CBS. 2015. Groeiend aantal Syriërs ingeschreven bij gemeenten. http://www.cbs.nl/nl-NL/menu/themas/dossiers/allochtonen/publi caties/artikelen/archief/2015/groeiend-aantal-syriers-ingeschrevenbij-gemeenten.htm. Accessed 17 Dec 2015.

CMO. 2015. Visie, missie en inspiratie. http://cmoweb.nl/index.php/ component/content/article?id=73. Accessed 10 July 2015.

CMO, Halal Correct, HVV, and Green Moslims Foundation. 2011. Letter about the CEN halal standardization project. http://www. groenemoslims.nl/wp-content/uploads/CEN-halal-standardizationproject-statement1.pdf. Accessed 31 Mar 2016.

Coicaud, J.M. 1997. Légitimité et politique. Contribution a l'étude du droit et de la responsabilité politiques. Presses Universitaires de France. English edition: Coicaud, J.M. 2002. Legitimacy and politics: a contribution to the study of political right and political responsibility (trans: David Ames Curtis). Cambridge, UK: Cambridge University Press.

Fischer, J. 2008. Feeding secularism: The halal market in London. https://www.researchgate.net/publication/238675535_Feeding_ Secularism_The_Halal_Market_in_London. Accessed 31 Mar 2016.

Fischer, J. 2015. Malaysian diaspora strategies in a globalized Muslim market. Geoforum 59: 169-177.

Fischler, C. 1988. Food, self and identity. Social Science Information 27(2): 275-292.

Fuchs, D., and A. Kalfagianni. 2010. The causes and consequences of private food governance. Business and Politics 12(3): 1-34.

Fuchs, D., A. Kalfagianni, J. Clapp, and L. Busch. 2011. Introduction to symposium on private agrifood governance: Values, shortcomings and strategies. Agriculture and Human Values 28(3): $335-344$.

Glasbergen, P. 2007. Setting the scene: The partnership paradigm in the making. In Partnerships, governance and sustainable development: Reflections on theory and practice, ed. P. Glasbergen, F. Biermann, and A. Mol, 1-25. Cheltenhem: Edward Elgar Publishing Limited.

Glasbergen, P. 2013. Legitimation of certifying partnerships in the global market place. Environmental Policy and Governance 23(6): 354-367.

Hachez, N., and J. Wouters. 2011. A glimpse at the democratic legitimacy of private standards. Assessing the public accountability of global G.A.P. Journal of International Economic Law 14(3): 677-710

Halal Malaysia Official Portal. 2015. Malaysian Standard on Halal Food (MS 1500:2009). http://www.halal.gov.my/v4/index.php/ en/garis-panduan/standard-malaysia. Accessed 09 July 2015.

Havinga, T. 2010. Regulating halal and kosher foods: Different arrangements between state, industry and religious actors. Erasmus Law Review 3(4): 156-241. 
Havinga, T., and C. Gerards. 2011. Halal en koosjercertificering in Nederland. Een verkennend onderzoek naar de regulering van halal en koosjer voedsel in Nederland. In Nijmegen Sociology of Law Working Papers Series 2011/02, eds. T. Havinga, F. Kulk, and A. Böcker. Nijmegen.

IHI Alliance. 2011a. Background. http://www.ihialliance.org/back ground.php. Accessed 06 Aug 2015.

IHI Alliance. 2011b. Welcome to IHI Alliance. http://www.ihialli ance.org/home.php. Accessed 10 July 2015.

Isa, N.M., and S. Man. 2014. "First Things First": Application of Islamic principles of priority in the ethical assessment of genetically modified foods. Journal of Agricultural and Environmental Ethics 27(5): 857-870.

ISEAL Alliance. 2013. ISEAL Credibility Principles. http://www. isealalliance.org/our-work/defining-credibility/credibility-princi ples. Accessed 31 Mar 2016.

Jessop, B. 2003. Governance and meta-governance: On reflexivity, requisite variety and requisite irony. In Governance as social and political communication, ed. H.P. Bang, 101-116. Manchester, UK: Manchester University Press.

KasehDia Sdn Bhd. 2009. World Halal Forum Europe: Post Event Report. http://www.worldhalalforum.org/download/WHF09Euro peGenericReport.pdf. Accessed 31 Mar 2016.

Keuringsdienst van Waarde. 2010. Döner. http://keuringsdienstvan waarde.kro.nl/seizoenen/2010/30-39057-21-01-2010. Accessed 24 Aug 2015.

Khan, Z. 2000. Muslim presence in Europe: The British dimensionidentity, integration and community activism. Current Sociology 48(4): 29-43. doi:10.1177/0011392100048004004.

Khenfer, J., and E. Roux. 2012. How does religion matter in the marketplace for minority settings? The case of Muslim consumers in France. Paper presented at the EMAC 42nd Conference. Lisbon, Portugal. May 2012.

KPMG. 2013. Improving smallholder livelihoods: Effectiveness of certification in coffee, cocoa and cotton. http://www.sustaineo.org/ tl_files/Sustaineo/Improving\%20smallholder\%20livelihoods\%20-\% 20Effectiveness $\% 20$ of $\% 20$ certification $\% 20 \mathrm{in} \% 20$ coffee, cocoa $\% 20$ and $\% 20$ cotton_study $\% 20$ commissioned $\% 20$ by $\% 20$ SUSTAINEO. pdf. Accessed 31 Mar 2016.

Lever, J. 2015. Re-imagining Malaysia: A postliberal halal strategy? In Halal Matters: Islam, politics and markets in global perspective, ed. F. Bergeaud-Blackler, J. Fischer, and J. Lever, 19-37. London, UK: Routledge.

Lever, J., and M. Miele. 2012. The growth of halal meat markets in Europe: An exploration of the supply side theory of religion. Journal of Rural Studies 28(4): 528-537.

Lewandowski, I., and A.P.C. Faaij. 2006. Steps towards the development of a certification system for sustainable bio-energy trade. Biomass and Bioenergy 30: 83-104.

Maliepaard, M., and M. Gijsberts. 2012. Moslim in Nederland 2012. www.ru.nl/publish/pages/671794/moslim_in_nederland_1.pdf. Accessed 31 Mar 2016.

Manger, L.O. 1999. Muslim diversity. Local Islam in global contexts. Richmond, UK: Curzon Press.

Mintz, S.W., and C.M. Du Bois. 2002. The anthropology of food and eating. Annual Review of Anthropology 31: 99-119.

Moslim Omroep. 2015. Hoe halal is halal? http://www.npo.nl/modoc-hoe-halal-is-halal/28-06-2015/VPWON_1244711. Accessed 10 July 2015.

MUI LPPOM. 2015. LPPOM MUI Pioneer Of Halal Standard \& Founder Of World Food Halal Council. http://www.halalmui. org/newMUI/index.php/main/go_to_section/2/31/page/2. Accessed 10 July 2015.

Nanz, P., and J. Steffek. 2004. Global governance, participation and the public sphere. Government and Opposition 39(2): 314-335.
Nolles, J. 2015. Maak je spullen halal en je verkoopt nog meer. De Volkskrant, 24 June, 30-31.

Pew Research Center. 2011. The future of the global muslim population. projections for 2010-2030. http://www.pewforum.org/files/2011/ 01/FutureGlobalMuslimPopulation-WebPDF-Feb10.pdf. Accessed 31 Mar 2016.

Quaedvlieg, J., M. García Roca, and M.A.F. Ros-Tonen. 2014. Is Amazon nut certification a solution for increased smallholder empowerment in Peruvian Amazonia? Journal of Rural Studies 33: 41-55.

Regenstein, J.M., M.M. Chaudry, and C.E. Regenstein. 2003. The kosher and halal food laws. Comprehensive Reviews in Food Science and Food Safety 2(3): 111-127.

Schouten, G., and P. Glasbergen. 2011. Creating legitimacy in global private governance: The case of the Roundtable on Sustainable Palm Oil. Ecological Economics 70(11): 1891-1899.

Shadid, W.A.R., and P.S. Van Koningsveld. 1992. Islam in dutch society: Current developments and future prospects. Kampen, the Netherlands: Kok Pharos Publishing House.

Sleegers, F. 2007. In debat over Nederland: Veranderingen in het discours over de multiculturele samenleving en nationale identiteit. Amsterdam, The Netherlands: Amsterdam University Press.

Slootman, M. 2015. Substantive signifiers? Ethnic and religious identifications among second-generation immigrants in the Netherlands. Identities: 1-19.

SMIIC. 2015. History of SMIIC. http://www.smiic.org/smiic. Accessed 06 Aug 2015.

Smits, M.J.W., and J. Van den Berg. 2003. Diversiteitsbeleid: (h)erkennen van meerstemmigheid. http://edepot.wur.nl/37708. Accessed 31 Mar 2016.

Steffek, J. 2009. Discursive legitimation in environmental governance. Forest Policy and Economics 11(5): 313-318.

Stichting Halal Voeding en Voedsel. 2014. Beleidsplan Stichting Halal Voeding en Voedsel voor de jaren 2014 tot en met 2018. http://www.halal.nl/wp-content/uploads/2011/07/Beleidsplan-HVV2014-2018-Definitief.pdf. Accessed 13 Jan 2016.

Suchman, M.C. 1995. Managing legitimacy: Strategic and institutional approaches. Academy of Management Review 20(3): 571-610.

Thomson Reuters. 2014. State of the global islamic economy 2014-2015 report. http://www.flandersinvestmentandtrade.com/ export/sites/trade/files/news/342150121095027/342150121095 027_1.pdf. Accessed 13 Jan 2016.

Tieman, M., M.C. Ghazali, and J.G.A.J. Van der Vorst. 2013. Consumer perception on halal meat logistics. British Food Journal 115(8): 1112-1129. doi:10.1108/bfj-10/2011-0265.

Tieman, M., and M.C. Ghazali. 2014. Halal control activities and assurance activities in halal food logistics. Procedia-Social and Behavioral Sciences 121: 44-57.

Trouw. 2013. Nederlander lijkt centrale figuur in paardenvleesschandaal. http://www.trouw.nl/tr/nl/4516/Gezondheid/article/detail/ 3393909/2013/02/14/Nederlander-lijkt-centrale-figuur-in-paarden vleesschandaal.dhtml. Accessed 06 Aug 2015.

Van der Spiegel, M., H.J. Van der Fels-Klerx, P. Sterrenburg, S.M. Van Ruth, I.M.J. Scholtens-Toma, and E.J. Kok. 2012. Halal assurance in food supply chains: Verification of halal certificates using audits and laboratory analysis. Trends in Food Science \& Technology 27(2): 109-119.

Van Waarden, F., and R. Van Dalen. 2011. Hallmarking halal. The market for halal certificates: Competitive private regulation. In Jerusalem Papers in Regulation \& Governance. Jerusalem.

Van Waarden, F., and R. Van Dalen. 2013. Halal and the moral construction of quality: How religious norms turn a mass product into a singularity. In Constructing quality: The classification of goods in markets, ed. J. Beckert, and C. Musselin, 197-222. Oxford, UK: Oxford University Press. 
Wallet, B. 2012. Ritueel slachten en godsdienstvrijheid in een seculiere samenleving. Religie \& Samenleving 7(2): 166-183.

Weller, D.L., and D. Turkon. 2015. Contextualizing the immigrant experience: The role of food and foodways in identity maintenance and formation for first- and second-generation latinos in Ithaca, New York. Ecology of Food and Nutrition 54(1): 57-73.

WHC. 2015. Members. http://www.worldhalalcouncil.com/members. Accessed 06 Aug 2015.

Laura Kurth is a Ph.D. researcher at Maastricht University (International Centre for Integrated Assessment and Sustainable
Development). Her main research interest concerns the role of religion in multicultural societies, multicultural policy making and the governance of religious food markets.

Pieter Glasbergen is honorary professor at Maastricht University (International Centre for Integrated Assessment and Sustainable Development) and emeritus Professor of Environmental Studies, Policy and Management at Utrecht University and the Dutch Open University. He chairs the Maastricht-Utrecht-Nijmegen Programme on Partnerships. His main expertise is in governance, planning and policy issues related to sustainable development. 